\title{
Thermoplastic Elastomers Containing Zinc Oxide as Antimicrobial Additive Under Thermal Accelerated Ageing
}

\author{
Douglas Naue Simões ${ }^{a, b} *$, Michele Pittol ${ }^{b}$, Daiane Tomacheski ${ }^{a, b}$, Vanda Ferreira Ribeiro ${ }^{a, b}$, \\ Ruth Marlene Campomanes Santana ${ }^{a}$ \\ aPrograma de Pós Graduação em Engenharia de Minas, Metalúrgica e de Materiais - PPGE3M, \\ Universidade Federal do Rio Grande do Sul, Porto Alegre, RS, Brazil \\ ${ }^{b}$ Softer Brasil Compostos Termoplásticos LTDA, Campo Bom, RS, Brazil
}

Received: October 24, 2016; Revised: June 21, 2017; Accepted: July 21, 2017

\begin{abstract}
Styrene-ethylene/butylene-styrene (SEBS) copolymer- based thermoplastic elastomers (TPE) are applied in the production of household items used in places with conditions for microbial development. Metal oxides like zinc oxide $(\mathrm{ZnO})$ and others can be added to the TPE composition to prevent microbial growth. The aim of this study is to evaluate the effect of thermal accelerated ageing on mechanical, chemical and antibacterial properties of SEBS-based TPE containing $0 \%, 1 \%, 3 \%$, and $5 \%$ zinc oxide. Zinc oxide was characterized by laser diffraction, X-ray diffraction, superficial area, porosity and scanning electron microscopy. Both aged and unaged samples were analyzed by infrared spectroscopy, tensile at rupture, elongation at rupture, hardness and antimicrobial activity against Escherichia coli and Staphylococcus aureus. Following thermal exposure, a reduction of antimicrobial activity was observed. No significant difference was observed in the chemical and mechanical characteristics between aged and unaged samples.
\end{abstract}

Keywords: Thermal degradation, mechanical properties, antimicrobial properties, thermoplastic elastomer, zinc oxide.

\section{Introduction}

Styrene-ethylene/butylene-styrene (SEBS) copolymerbased thermoplastic elastomers (TPE) are used in a broad range of applications such as the automotive industry, wire and cable coating, medical devices, footwear, personal products, household items, and others ${ }^{1,2}$. Under working conditions, polymers are degraded by environmental agents such as mechanical stress, heating/cooling, chemicals and hydrolysis ${ }^{3,4}$. These injuries make the polymer prone to bacterial colonization that results in the transmission of diseases, product deterioration, undesirable staining ${ }^{5}$ and economic losses ${ }^{6}$. The TPE materials susceptibility to microbial attacks increases in humid environments with high concentrations of organic matter ${ }^{7,8}$.

Long-term protection from such damage can involve the incorporation of antimicrobial agents into the polymer matrix. This way, in order to prevent microorganism access, organic and inorganic antimicrobial additives have been used to produce antimicrobial materials ${ }^{9}$. However, TPE production comprises extrusion and injection steps that submit the compound to elevated temperatures and high shear rate that degrade the organic additives ${ }^{2}$. From this angle, inorganic additives such as zinc oxide $(\mathrm{ZnO})^{10}$ are being used due to their chemical and thermal stability ${ }^{11}$. A field of application for products with antimicrobial properties is on utensils that are used in high humidity environments such as bathroom and kitchen (including bath mats, sponges), as well as outdoor products, including furniture and decking ${ }^{12}$.

Studies of the effects of $\mathrm{ZnO}$ incorporation in TPE properties are needed in order to define the effectiveness and applicability of the material both initially and during the product life cycle. The aim of this study is investigate the effect of accelerated ageing on mechanical, chemical and antibacterial properties of SEBS-based TPE containing zinc oxide.

\section{Experimental}

\subsection{Materials}

The materials used in this study were two different $\mathrm{ZnO}$ based additives referred to as follows: zinc oxide Perrin (ZnO-Pe) supplied by Perrin S. A. and zinc oxide WR (ZnOWR) supplied by WR Cerâmica. The additive concentrations used were $1.0 \%, 3.0 \%$ and $5.0 \%$ weight of $\mathrm{ZnO}$ (Table 1 ). The additives were added to a TPE formulation compounded by styrene-ethylene/butylene-styrene copolymer (SEBS), polypropylene homopolymer (PP), mineral oil, calcite and an antioxidant to avoid thermal degradation during processing. A compound with no antimicrobial additive (C-00) was also tested. 
Table 1. Identification of zinc oxide loaded in TPE compounds.

\begin{tabular}{lcc}
\hline Compound name & $\begin{array}{c}\text { Amount of } \\
\text { additive }(\% \mathrm{wt})\end{array}$ & Additive \\
\hline $\mathrm{C}-00$ & 0 & No additive \\
$\mathrm{C}-\mathrm{ZnOPe}-1$ & 1 & $\mathrm{ZnO}-\mathrm{Pe}$ \\
$\mathrm{C}-Z n O P e-3$ & 3 & $\mathrm{ZnO}-\mathrm{Pe}$ \\
$\mathrm{C}-\mathrm{ZnOPe}-5$ & 5 & $\mathrm{ZnO}-\mathrm{Pe}$ \\
$\mathrm{C}-\mathrm{ZnOWR}-1$ & 1 & $\mathrm{ZnO}-\mathrm{WR}$ \\
$\mathrm{C}-Z n O W R-3$ & 3 & $\mathrm{ZnO}-\mathrm{WR}$ \\
$\mathrm{C}-Z n O W R-5$ & 5 & $\mathrm{ZnO}-\mathrm{WR}$ \\
\hline
\end{tabular}

\subsection{Characterization of the additives}

The $\mathrm{ZnO}$ particle size was described by laser diffraction, using a CILAS 1180 particle size analyzer, with scanning ranging from $0.04 \mu \mathrm{m}$ to $2500 \mu \mathrm{m}$. The X-ray diffraction (XRD) was performed by Philips X'Pert MDP diffractometer with $\mathrm{Cu} \mathrm{K} \alpha$ radiation to define chemical composition and purity.

The superficial area and porosity of the additives were measured by Barret-Joyner-Halenda (BJH) method with a Nova Station A (Quantachrome Instruments). The patterns of adsorption and desorption isotherms of nitrogen were measured at $-196{ }^{\circ} \mathrm{C}$, before adsorption, the sample was degassed at $300{ }^{\circ} \mathrm{C}$ for $0.4 \mathrm{~h}$.

Scanning electron microscopy (SEM) and energy dispersive $\mathrm{X}$-ray spectrometry (EDS) was carried out to verify the $\mathrm{ZnO}$ morphology and chemical composition. The analyses were performed in a carbon type stuck to stub. To obtain images were used a Jeol JSM 6010LA microscope operating at 15 $\mathrm{kV}$ and the samples were metalized with gold.

\subsection{Preparation of compounds}

The samples were prepared using a co-rotating double screw extruder (L/D 40 and $16 \mathrm{~mm}$ screw diameter, $\mathrm{AX}$ Plásticos) with temperature profile from $150^{\circ} \mathrm{C}$ to $190^{\circ} \mathrm{C}$ at a speed of $226 \mathrm{rpm}$. During testing, the extrusion parameters were kept constant. Test specimens in plate form with $2 \mathrm{~mm}$ thickness were prepared using an injection molding machine (Haitian, PL860) at $190^{\circ} \mathrm{C}$.

\subsection{Characterization of compounds}

The specimens were submitted to accelerated ageing in an oven at $105^{\circ} \mathrm{C}$ during 168 hours according to ASTM D 573.

Mechanical properties were tested in aged and unaged samples. The tensile at rupture and elongation at rupture of the compounds were obtained by tensile testing and analyzed according to ASTM D 412C in an EMIC DL 2000 machine. For tensile at rupture and elongation at rupture analyses were run ten replicates. Hardness was tested according to ASTM D 2240 in durometer Bareiss model HPE A, with an indentation hardness time of 3 seconds. For hardness analyses were run twenty five replicates.
Fourier transformed infrared spectroscopy (FTIR) with attenuated total reflection (ATR) was recorded on a PerkinElmer spectroscope (Frontier). Each spectrum was recorded from a total of 10 scans at a resolution of $4 \mathrm{~cm}^{-1}$ and at room temperature. Spectrum software was used for spectra analysis.

\subsection{Reduction of bacterial population}

Japan industrial standard (JIS) Z $2801^{13}$ was applied to evaluate antibacterial efficiency of samples against the bacterial species Escherichia coli ATCC 8739 (E. coli) and Staphylococcus aureus ATCC 6538 (S. aureus). Prior the test, the TPE samples (plaques - $50 \mathrm{~mm}$ x $50 \mathrm{~mm}$ ) were disinfected with ethanol and then exposed to ultraviolet (UV) light with the wavelength between $300 \mathrm{~nm}$ and 400 $\mathrm{nm}$ for $2 \mathrm{~h}$. The distance between the UV light and the specimen was kept at $10 \mathrm{~cm}$. After that, each TPE sample was placed separately in a sterile Petri dish and a bacterial suspension was applied to the sample surface. All of them were incubated for $24 \mathrm{~h}$ at $35 \pm 1^{\circ} \mathrm{C}$.

The variation of bacterial population was calculated by applying the equation (1):

$$
V=\frac{(N f-N i)}{N i} \times 100
$$

Where,

$\mathrm{V}=$ variation of bacterial population in percentage $(\%)$;

$\mathrm{N} i=$ number of bacteria incubated on TPE sample at zero hour;

$\mathrm{N} f=$ number of bacteria after 24 hours of incubation on TPE sample.

\subsection{Statistical analyses}

Analysis of variance and t-test were carried out for comparing averages of tensile at rupture, elongation at rupture, hardness and antimicrobial results using MYSTAT student version 12 (Systat Software, Inc., CA, USA). The level of significance was set at $(\mathrm{p} \leq 0.05)$.

\section{Results and Discussion}

\subsection{Characterization of the additives}

To understand the physical, mechanical and antimicrobial properties of $\mathrm{ZnO}$ based TPE compounds it is necessary to know the additives characteristics, such as size and morphology ${ }^{14-16}$.

The XRD results show the presence of one phase of $\mathrm{ZnO}$ in both particles tested. The additives showed hexagonal symmetry named as wurtzite structure of $\mathrm{ZnO}^{17,18}$. The wurtzite unit cell parameters of both additives were near to ideal crystal. The deviation in $\mathrm{ZnO}-\mathrm{Pe}$ and $\mathrm{ZnO}-\mathrm{WR}$ wurtzite is natural and can be due to the lattice stability and ionicity ${ }^{19}$. 
Table 2 shows particles size determined by laser diffraction, surface area and porosity determined by BJH method. The zinc oxide A has an average size of $1.52 \mu \mathrm{m}$ higher than zinc oxide B that presented the size of 1.05 $\mu \mathrm{m}$. In addition, zinc oxide B has higher surface area and porosity than zinc oxide $\mathrm{A}$.

Table 2. Particle size, surface area and porosity of the additives used.

\begin{tabular}{lccc}
\hline Additive & Dmean $(\mu \mathrm{m})$ & $\begin{array}{c}\text { Surface area } \\
\left(\mathrm{m}^{2} / \mathrm{g}\right)\end{array}$ & $\begin{array}{c}\text { Porosity } \\
\left(\mathrm{cm}^{3} / \mathrm{g}\right)\end{array}$ \\
\hline ZnO-Pe & 1.52 & 3.148 & 0.008 \\
ZnO-WR & 1.05 & 5.910 & 0.015 \\
\hline
\end{tabular}

Figure 1 show micrographs of the morphology of zinc additives used. Both particles present irregular shape and an average size of $0.4 \mu \mathrm{m}$, lower than that found in XRD assay. In Figure 1 it is possible to see that the $\mathrm{ZnO}$ particles have tendency to agglomeration.

The dispersive energy analysis showed peak in $0.2 \mathrm{keV}$ typical of carbon (C) which originated from the technique of sample preparation. The peak $0.5 \mathrm{keV}$ is typical oxygen $(\mathrm{O})$, and the peaks $0.9,1.0,8.6$ and $9.6 \mathrm{keV}$ are typical of zinc $(\mathrm{Zn})^{20}$ from the additives $\mathrm{ZnO}-\mathrm{Pe}$ and $\mathrm{ZnO}-\mathrm{WR}$. Further, no analysis found any impurity in both additives, $\mathrm{ZnO}-\mathrm{Pe}$ and $\mathrm{ZnO}-\mathrm{WR}$.

\subsection{Mechanical properties}

Tensile strength at rupture and elongation at rupture values of aged and unaged compounds are shown in Figure 2 and Figure 3, respectively.

An increase in tensile strength at rupture of unaged compounds (Figure 2) can be observed. Because the inorganic particle usually promotes a reinforcing effect on the SEBS/ PP matrix ${ }^{21}$, an increase was expected in tensile values with the rise in the additive amount.

The differences in tensile strength at rupture and elongation at rupture between aged and unaged samples

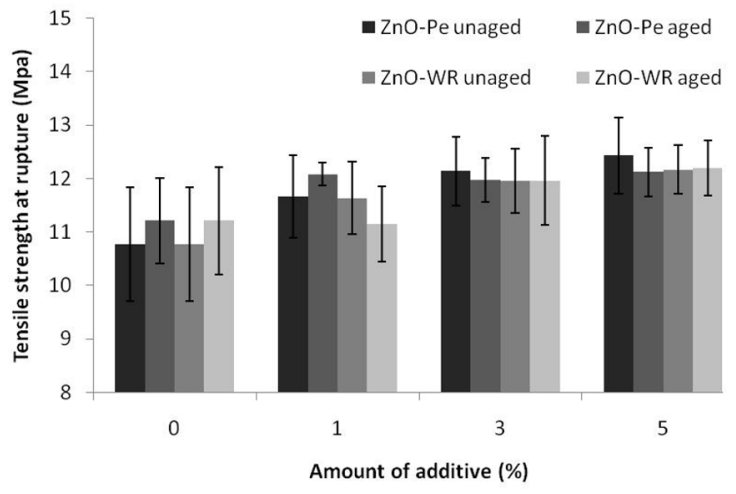

Figure 2. Variation in tensile strength at rupture of aged and unaged $\mathrm{ZnO}$ loaded TPE compounds. Error bars means $\pm \mathrm{SD}$ of ten replicates.

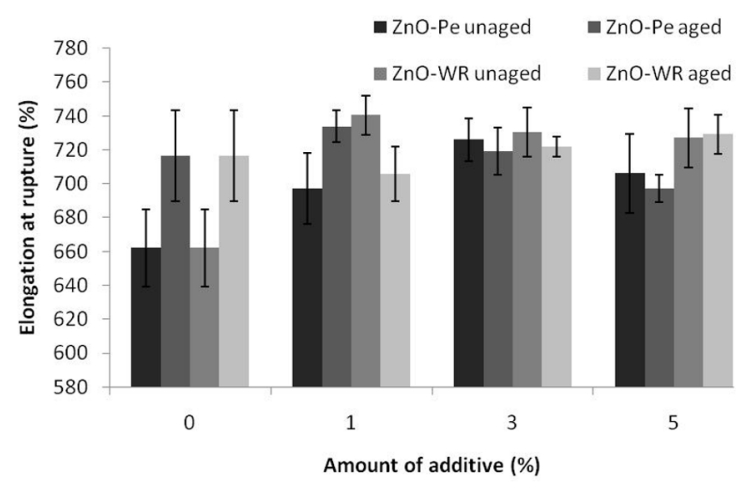

Figure 3. Variation in elongation at rupture of aged and unaged $\mathrm{ZnO}$ loaded TPE compounds. Error bars means $\pm \mathrm{SD}$ of ten replicates.

were not significant (Figure 2 and Figure 3). The same trend was observed in hardness values (Table 3 ). TPE compounds usually feature a decrease in mechanical properties after being submitted to accelerated ageing, a behavior that has been related to chain scission ${ }^{22}$. However, in this case the blend of SEBS with PP forms a co-continuous phase which provides thermal stability to the compound due the high temperature degradation of PP as well as the saturated middle block of SEBS ${ }^{1,4}$.
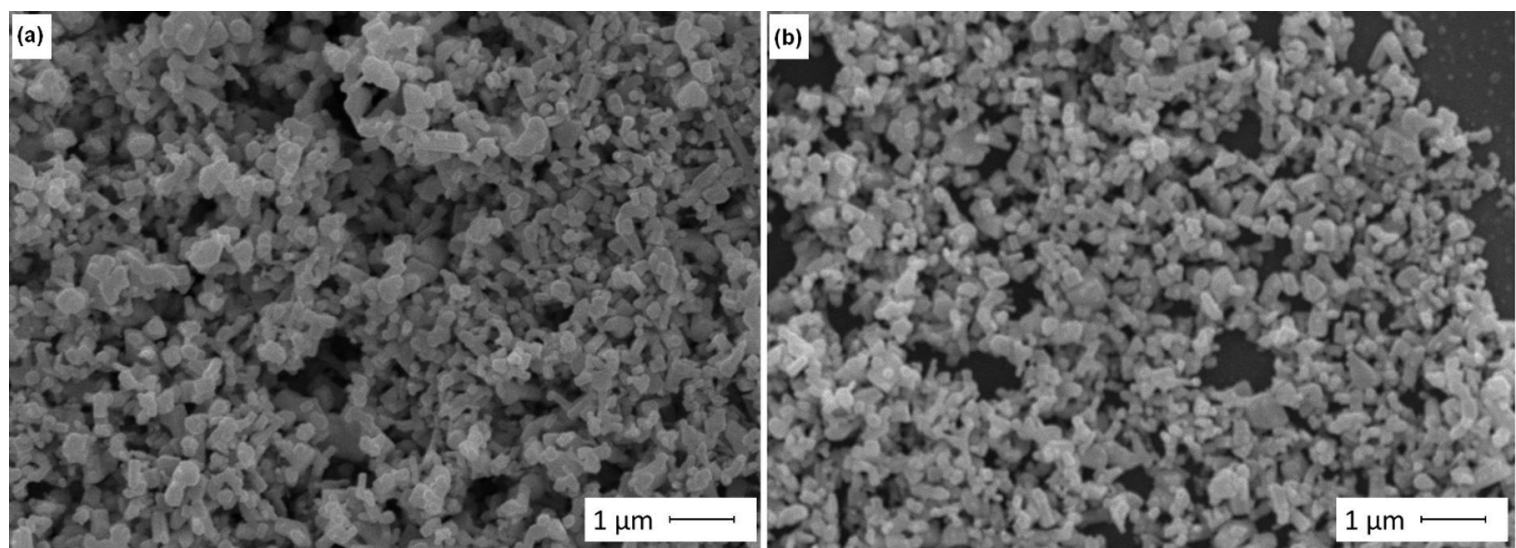

Figure 1. Micrographs of the morphology of the additives: (a) $\mathrm{ZnO}-\mathrm{Pe}$ and (b) $\mathrm{ZnO}-\mathrm{WR}$. 
Table 3. Median values of hardness in aged and unaged $\mathrm{ZnO}$ loaded TPE compounds.

\begin{tabular}{lcc}
\hline Sample & $\begin{array}{c}\text { Unaged* Hardness } \\
\text { (Shore A) }\end{array}$ & $\begin{array}{c}\text { Aged*Hardness } \\
\text { (Shore A) }\end{array}$ \\
\hline C-00 & $79.5 \pm 0.6$ & $78.3 \pm 1.5$ \\
C-ZnOPe-1 & $78.5 \pm 0.5$ & $78.6 \pm 0.9$ \\
C-ZnOPe-3 & $78.9 \pm 0.6$ & $78.4 \pm 0.7$ \\
C-ZnOPe-5 & $79.5 \pm 0.6$ & $79.1 \pm 1.0$ \\
C-ZnOWR-1 & $77.7 \pm 0.9$ & $77.7 \pm 0.8$ \\
C-ZnOWR-3 & $78.5 \pm 0.7$ & $78.4 \pm 0.6$ \\
C-ZnOWR-5 & $78.8 \pm 0.6$ & $79.1 \pm 1.1$ \\
\hline
\end{tabular}

$*$ Means \pm SD of twenty five replicates.

\subsection{Chemical properties}

Figure 4 shows the FTIR-ATR spectrum of aged and unaged $\mathrm{ZnO}$ loaded TPE compounds. The spectrum depicts bands typically from TPE based on SEBS/PP/oil/calcite, such as the peaks at $2952 \mathrm{~cm}^{-1}, 1493 \mathrm{~cm}^{-1}, 757 \mathrm{~cm}^{-1}$ and 698 $\mathrm{cm}^{-1}$ that are common in aromatic compounds, the peaks at 2920 and $2852 \mathrm{~cm}^{-1}$ attributed to $\mathrm{C}-\mathrm{H}$ vibrations. Also, bands were found at 1455 and $1377 \mathrm{~cm}^{-1}$ corresponding to methyl group and at $876 \mathrm{~cm}^{-1}$ which represents carbonyl group from $\mathrm{CaCO}_{3}{ }^{23-27}$. There were no differences in the FTIR-ATR profiles between aged and unaged compounds. Similar behavior has been previously reported in a polymer composite based on SEBS, which presented no modifications on chemical profile after accelerated ageing ${ }^{28}$.

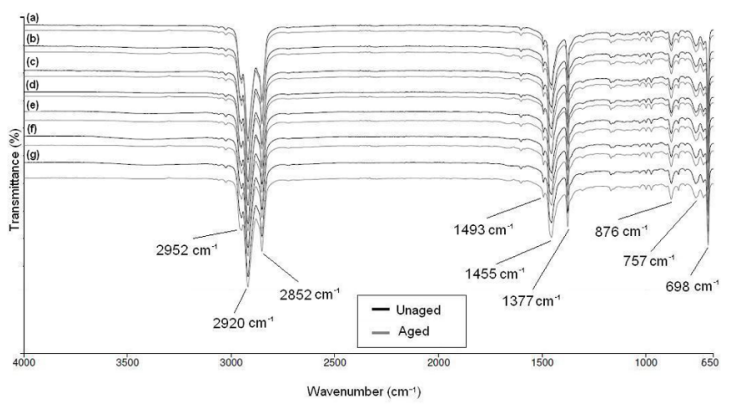

Figure 4. FTIR spectra of compounds (a) C-00, (b) C-ZnOPe-1, (c) C-ZnO-Pe3, (d) CZnOPe-5, (e) C-ZnOWR-1, (f) C-ZnOWR-3 and (g) C-ZnOWR-5.

\subsection{Antimicrobial properties}

Figure 5 shows the variance in $E$. coli (Figure 5a) and $S$. aureus (Figure 5b) population in aged and unaged $\mathrm{ZnO}$ loaded compounds. A significant difference $(\mathrm{p}<0.05)$ was observed in E. coli and S. aureus counts between the compounds loaded with different amounts of $\mathrm{ZnO}$.

The $\mathrm{ZnO}$ loaded TPE compounds featured an antimicrobial action, with a reduction of between $42.0 \%$ and $79.4 \%$ in the E. coli population (Figure $5 \mathrm{a}$ ), and between $49.2 \%$ and $75.0 \%$ in the $S$. aureus population (Figure $5 \mathrm{~b}$ ). The antibacterial activity improved with increased concentration of the additive,

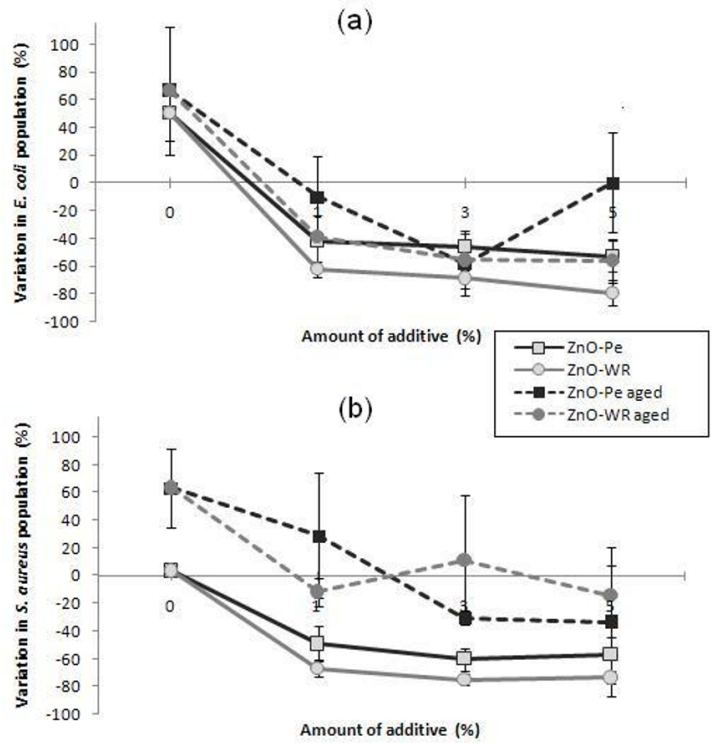

Figure 5. Variation in (a) E. coli and (b) S. aureus population in aged and unaged $\mathrm{ZnO}$ loaded TPE compounds. Error bars means $\pm \mathrm{SD}$ of three replicates.

with better biocide action observed in samples loaded with $5 \%$ of $\mathrm{ZnO}$. The antimicrobial mechanisms of $\mathrm{ZnO}$ may be related to reactive oxygen substances produced by hydrogen peroxide which causes damage to prokaryotic cells ${ }^{29}$.

After thermal ageing, the $\mathrm{ZnO}$ loaded compounds showed a loss of antibacterial activity when compared to unaged compounds. This difference was significant against the $E$. coli population (in C-ZnOWR-1 sample), and against $S$. aureus (in C-ZnOPe-1, C-ZnOPe-3, C-ZnOWR-1, C-ZnOWR-3 and C-ZnOWR-5 samples). This increased susceptibility to microbial attack in aged samples may be related to the presence of chemical substances from polymer degradation.

Carbonyl groups resulting from the oxidation of polypropylene ${ }^{30}$ and residues from the spin-off of ethylenebutylene links with styrene chains of SEBS ${ }^{31}$ may have produced a favorable environment for adherence and proliferation of bacteria. Furthermore, although it was not verified in the FTIR profile, the waste layer of polymer degradation may have prevented contact between the bacterial cell and the additive.

\section{Conclusion}

The $\mathrm{ZnO}$ loaded TPE compounds did not present any significant modification in the mechanical properties even after exposure to thermal ageing. Although a reduction in biocide action was observed, the aged samples still featured an antimicrobial property. Further studies are needed to learn about the reasons for the reduction in antibacterial activity even with no polymer degradation, and also about what amount of additive offers the best efficacy.

Lastly, the findings reveal the potential of $\mathrm{ZnO}$ loaded SEBS-based thermoplastic elastomers to produce daily use 
items that are routinely exposed to thermal action and that with additional cleaning treatment can prevent bacterial contamination.

\section{Acknowledgments}

The authors are grateful to FINEP for the financial support (03.13.0280.00) and Softer Brasil Compostos Termoplásticos LTDA.

\section{References}

1. Drobny JG. Handbook of Thermoplastic Elastomers. Norwich: William Adrew Publishing; 2007.

2. Shanks R, Kong I. Termoplastic Elastomers. In: El-Sonbati AZ, ed. Termoplastic Elastomers. $1^{\text {st }}$ ed. Rijeka: InTech; 2012. p. 137-154.

3. Shah AA, Hasan F, Hameed A, Ahmed S. Biological degradation of plastics: A comprehensive review. Biotechnology Advances. 2008;26(3):246-265.

4. Swift G, Baciu R, Chiellini E. Environmentally Degradable Polyolefins. In: Celina MC, Billingham NC, Wiggins JS, eds. Polymer Degradation and Performance. ACS Symposium Series. Washington: American Chemical Society; 2009.

5. Kneale C. Problems and Pitfalls in the Evaluation and Design of New Biocides for Plastic Applications. Polymers \& Polymer Composites. 2003;11(3):219-227.

6. Nostro A, Scaffaro R, D'Arrigo M, Bott L, Filocamo A, Mariano A, et al. Development and characterization of essential oil component-based polymer films: a potential approach to reduce bacterial biofilm. Applied Microbiology and Biotechnology. 2013;97(21):9515-9523.

7. Andersson MA, Nikulin M, Köljag U, Andersson MC, Rainey F, Reijula K, et al. Bacteria, molds, and toxins in water-damaged building materials. Applied and Enviromental Microbiology. 1997;63(2):387-393.

8. Gajanan MV, Singh OV. Isolation of microbes from common household surfaces. Journal of Emerging Investigators. 2013;1-7. Available from: $<$ http://emerginginvestigators.org/wp-content/ uploads/2013/01/Ganajan-and-Singh-JEI-2013.pdf $>$. Access in: $25 / 7 / 2017$

9. Nichols D. Biocides in Plastics. Shawbury: Rapra Review Reports; 2004.

10. Zhang L, Jiang Y, Ding Y, Daskalakis N, Jeuken L, Povey M, et al. Mechanistic investigation into antibacterial behaviour of suspensions of $\mathrm{ZnO}$ nanoparticles against E. coli. Journal of Nanoparticle Research. 2010;12(5):1625-1636.

11. Muñoz-Bonilla A, Fernández-García M. Polymeric materials with antimicrobial activity. Progress in Polymer Science. 2012;37(2):281-339.

12. Plastics Color introduces zinc-based antimicrobial, expands masterbatch production. Additives for Polymers. 2014;1:2-3.

13. Japanese Standards Association (JIS). JIS Z 2801:2010 Antimicrobial Products - Test for Antimicrobial Activity and Efficacy. Tokyo: JIS; 2010.
14. Jiang J, Li G, Ding Q, Mai K. Ultraviolet resistance and antimicrobial properties of $\mathrm{ZnO}$-supported zeolite filled isotactic polypropylene composites. Polymer Degradation and Stability. 2012;97(6):833-838.

15. Omar MF, Akil HM, Ahmad ZA, Mahmud S. The Effect of loading rates and particle geometry on compressive properties of polypropylene/zinc oxide nanocomposites: Experimental and numerical prediction. Polymer Composites. 2012;33(1):99-108.

16. Wen B, Ji B. Crystallization behaviors and mechanical performance of polypropylene/tetrapod-shaped zinc oxide whisker composites. Journal of Applied Polymer Science. 2012;124(1):138-144.

17. Özgür Ü, Alivov YI, Liu C, Teke A, Reshchikov MA, Dogan S, et al. A comprehensive review of $\mathrm{ZnO}$ materials and devices. Journal of Applied Physics. 2005;98(4):041301.

18. Geurts J. Crystal Structure, Chemical Binding, and Lattice Properties. In: Klingshirn CF, Meyer BK, Waag A, Hoffman A, Geuruts J. Zinc Oxide: From Fundamental Properities Towards Novel Applications. New York: Springer; 2010. p. 7-37.

19. Morkoç H, Özgür Ü. Zinc Oxide: Fundamentals, Materials and Device Technology. Weinheim: Wiley-VCH; 2009.

20. Majithia R, Speich J, Meissner KE. Mechanism of Generation of ZnO Microstructures by Microwave-Assisted Hydrothermal Approach. Materials. 2013;6:2497-2507.

21. Altan M, Yildirim H. Effects of compatibilizers on mechanical and antibacterial properties of injection molded nano- $\mathrm{ZnO}$ filled polypropylene. Journal of Composite Materials. 2012;46(25):3189-3199.

22. Zhang Z, Wang S, Zhang J. Large stabilizing effect of titanium dioxide on photodegradation of $\mathrm{PVC} / \alpha$-methylstyreneacrylonitrile copolymer/impact modifier-matrix composites. Polymer Composites. 2014;35(12):2365-2375.

23. Orlov AS, Kiselev SA, Kiseleva EA, Budeeva AV, Mashukov VI. Determination of styrene-butadiene rubber composition by attenued total internal reflection infrared spectroscopy. Journal of Applied Spectroscopy. 2013;80(1):47-53.

24. Pavia DL, Lampman GM, Kriz GS, Vyvyan JR. Introduction to Spectroscopy. 5 $^{\text {th }}$ ed. Delhi: Cengage Learning; 2013.

25. Zhao H, Hou Q, Hong Y, Liu W, Li Y, Tong F. Determination of calcium carbonate and styrene-butadiene latex content in the coating layer of coated paper. Journal of Industrial and Engineering Chemistry. 2014;20(4):1571-1576.

26. Valença DP, Alves KGB, Melo CP, Bouchonneau N. Study of the Efficiency of Polypyrrole/ZnO Nanocomposites as Additives in Anticorrosion Coatings. Materials Research. 2015;18(Suppl 2):273-278

27. Skrockienė V, Žukienė K, Jankauskaitė V, Baltušnikas A, Petraitienė S. Properties of mechanically recycled polycaprolactonebased thermoplastic polyurethane/polycaprolactone blends and their nanocomposites. Journal of Elastomers \& Plastics. 2016;48(3):266-286.

28. Costa P, Ribeiro S, Botelho G, Machado AV, Lanceros Mendez S. Effect of butadiene/styrene ratio, block structure and carbon nanotube content on the mechanical and electrical properties of thermoplastic elastomers after UV ageing. Polymer Testing. 2015;42:225-233. 
29. Sawai J, Shoji S, Igarashi H, Hashimoto A, Kokugan T, Shimizu $\mathrm{M}$, et al. Hydrogen peroxide as an antibacterial factor in zinc oxide powder slurry. Journal of Fermentation and Bioengineering. 1998;86(5):521-522.

30. Fechine GJM, Santos JAB, Rabello MS. Avaliação da fotodegradação de poliolefinas através da exposição natural e artificial. Química Nova. 2006;29(4):674-680.
31. Allen NS, Edge M, Wilkinson A, Liauw CM, Mourelatou D, Barrio J, et al. Degradation and stabilisation of styreneethylene-butadiene-styrene (SEBS) block copolymer. Polymer Degratation and Stability. 2001;71(1):113-122. 